4 norden 



\section{Development of the Nordic-Baltic Market for Organic Food}

TemaNord 2005:548 


\section{Development of the Nordic-Baltic Market for Organic Food}

TemaNord 2005:548

(C) Nordic Council of Ministers, Copenhagen 2005

ISBN 92-893-1182-7

Print: Only available as print on demand. Ekspressen Tryk \& Kopicenter

Layout: Publication Unit, NCM

Printed versions are printed on environmentally friendly paper

This publication can be ordered on www.norden.org/order. Other Nordic publications are available

at www.norden.org/publications

Printed in Denmark

Nordic Council of Ministers

Store Strandstræde 18

DK-1255 Copenhagen K

Phone (+45) 33960200

Fax (+45) 33960202

www.norden.org

\author{
Nordic Council \\ Store Strandstræde 18 \\ DK-1255 Copenhagen $\mathrm{K}$ \\ Phone (+45) 33960400 \\ Fax (+45) 33111870
}

\section{Nordic co-operation}

Nordic co-operation, one of the oldest and most wide-ranging regional partnerships in the world, involves Denmark, Finland, Iceland, Norway, Sweden, the Faroe Islands, Greenland and Åland. Cooperation reinforces the sense of Nordic community while respecting national differences and similarities, makes it possible to uphold Nordic interests in the world at large and promotes positive relations between neighbouring peoples.

Co-operation was formalised in 1952 when the Nordic Council was set up as a forum for parliamentarians and governments. The Helsinki Treaty of 1962 has formed the framework for Nordic partnership ever since. The Nordic Council of Ministers was set up in 1971 as the formal forum for co-operation between the governments of the Nordic countries and the political leadership of the autonomous areas, i.e. the Faroe Islands, Greenland and Åland. 


\section{Content}

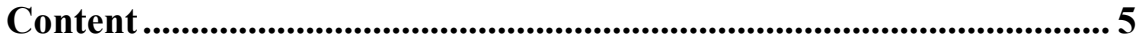

Executive Summary ........................................................................................ 7

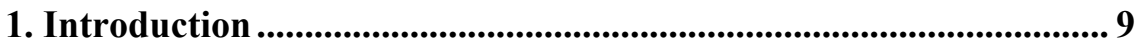

1.1 Background and Scope of the Project ............................................. 9

1.2 Chronology of the Project Activities ................................................. 10

1.3 Readers Guide to the Content of the Report...................................... 11

2. The Organic Market in the Nordic-Baltic Region............................ 13

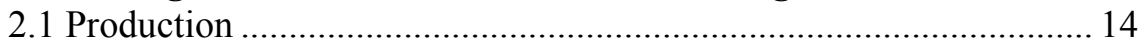

2.1.1 Organic Crops in the Nordic/Baltic countries..................................15

2.1.2 Organic Livestock....................................................................... 16

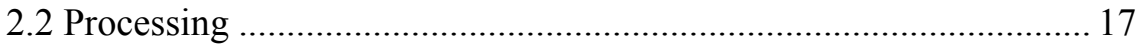

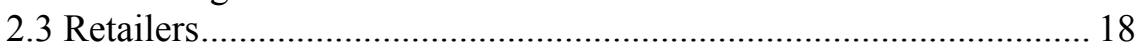

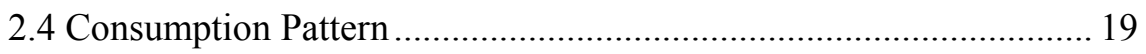

2.5 Import/Export of Organic Products .................................................... 19

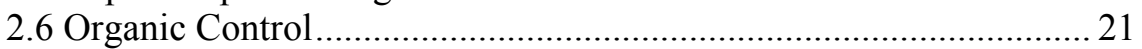

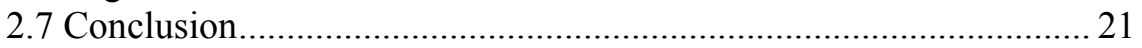

3. Barriers for Further Development of the Organic Market............ 23

3.1 Consumer awareness ..................................................................... 23

3.2 Deficient Market Data ...................................................................... 24

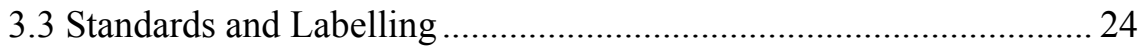

3.4 Lack of Marketing Channels .......................................................... 25

3.5 Lack of Processing and Innovation ................................................... 26

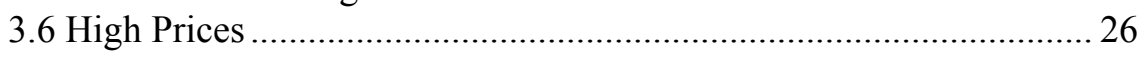

4. The Promotion Scheme ...................................................................29

4.1 Possible Organic Programmes ....................................................... 29

4.2 Other Key-conditions to Bear in Mind............................................... 31

4.3 Inspiration from Previous Programmes........................................... 33

4.3.1 Austrian Promotion Campaign ........................................................ 33

4.3.2 Denmark - A campaign for the organic EU-logo..................................34

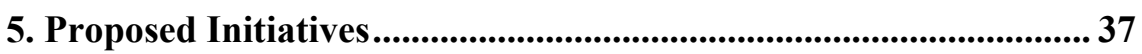

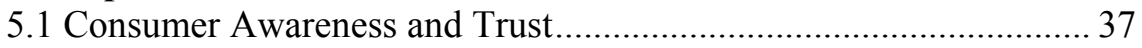

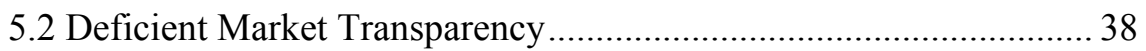

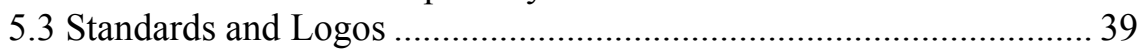

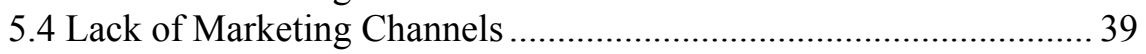

6. From Idea to Action .................................................................................. 43

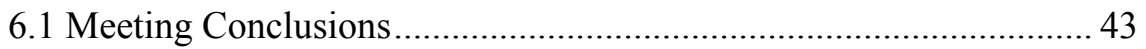

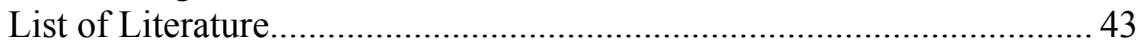

Sammenfatning.......................................................................................... 47

Annex 1: Relevant Links................................................................... 49

Annex 2: Organic Market Share in Norway, Sweden and Finland.. 51 


\section{Executive Summary}

This report contains the conclusions from the project "Development of the Nordic/Baltic Market for Organic Food" in which public authorities and NGO's from Denmark, Estonia, Finland, Latvia, Lithuania, Norway and Sweden have participated.

The objective of this project was to elaborate a joint project proposal in order to promote the development of the Nordic-Baltic market for organic products.

The project identifies and describes a range of barriers for a market driven development of the organic sector, including lack of consumer awareness, deficient market data, different standards and labelling, lack of marketing channels, lack of processing and innovation and high prices.

Against this background the project points out a range of potential cross-border activities, including an information campaign to raise awareness and induce consumers' trust in organic products, construction of a common information system on the rules and procedures, promotion of the EU-logo and national logos, collaboration between retail chains and representative organic organisations and finally alternative distribution channels.

In order to enable the implementation of one or more of these potential activities the project has identified relevant funding opportunities. The most relevant funding opportunity has been identified as the EU promotion scheme (Commission Legislation (EC) 94/2002 of 18 January 2002), which is therefore described thoroughly.

It should be emphasised that the project partners are not bound by the conclusions of the project. Hence, the funding and further elaboration of the proposals are left open. However, the Danish Directorate for Food, Fisheries and Agri Business has committed itself to elaborate an overall concept, which could provide a common denominator and an overarching framework for a campaign in which all the nations can participate. 


\section{Introduction}

\subsection{Background and Scope of the Project}

The organic market share of the total agricultural sector is still quite limited. Even for countries that holds the largest share of organic sales in the Nordic/Baltic region. Although currently a niche market, organic products is believed to have a very large potential for growth.

During the last couple of years the need to strengthen the Nordic and/or Nordic-Baltic co-operation within the organic sector has been addressed at several meetings between Nordic and Baltic Ministers.

At a meeting between Nordic ministers in Greenland August 2002 it was concluded that the Nordic co-operation within the organic sector should be strengthened. The Nordic ministers declared, that organic farming is important in order to ensure a sustainable agriculture, environment friendly methods of working and a wide supply of food in the region. Furthermore, the ministers agreed that the market should drive the further development of the organic sector. The declaration underlined that it was desirable to strengthen the Nordic co-operation within the organic sector ${ }^{1}$.

In continuation of the declaration a seminar was held in Hamar in Norway in October 2002. The participants were officials working with the organic sector in the Nordic countries. The aim was to examine the need for a strengthened co-operation between the Nordic Countries across a wider range of themes. The idea was that the Nordic countries to some extent face the same challenges in regard to organic production in spite of different developmental stages of organic production. Increased cooperation as well as an exchange of knowledge and experiences across the countries could therefore contribute to further development of the organic sector.

The effort was continued at a meeting held in Tallinn in November 2003. The ministers agreed on the Declaration on Organic Food and Agriculture Production in the Nordic-Baltic Region. The declaration aimed at enhanced co-operation in order to develop organic food and agriculture production in the Nordic-Baltic region.

The need for initiatives to strengthen the market for organic food was discussed during the seminar. It was agreed that strengthening of the market is an important condition for further development and consolidation of the organic production.

\footnotetext{
${ }^{1}$ In Norwegian: http://www.norden.org/pub/velfaerd/livsmedel/sk/ANP2002771.PDF, published by the Nordic Council.
} 
The tendency to focus on market-led development of the organic production was reinforced in the European Action Plan, launched by the European Commission in June 2004.

Against this background this project operates with two objectives:

- The immediate objective is the elaboration of a joint project proposal based on the identification of market challenges for organic products as presented by the participants. The project proposals will aim at Commission Legislation (EC) 94/2002 of 18 January 2002 laying down detailed rules for applying the Council Regulation (EC) No 2826/2000 on information and promotion actions for agricultural products on the internal market (The Promotion Scheme).

- The long-term objective is the development of the Nordic-Baltic market for organic products.

Until now there has only been limited contact within the region in regard to the market and trade aspects of organic production. However, since it is not regarded possible for any single partner to solve issues concerning market development and trade by itself a common steering committee was established in order to ensure joint efforts. The Nordic Council provided funds for the work.

The partners behind the project are not obliged to take part in such an application.

\subsection{Chronology of the Project Activities}

The Steering Committee held its first meeting in Denmark, 18 June, 2004. The initial discussion had a SWOT ${ }^{2}$ analysis as its starting point. National seminars followed with the purpose of providing input from national market actors and branch organisations. The seminars had the task of formulating ideas and identify main obstacles prohibiting development of the organic market, based on their own practical experiences. The aim was to gather knowledge on the exact needs of the market actors in regard to future development of the market.

The Steering Committee met for the second time in Finland, $20^{\text {th }}$ September 2004. The inputs from the national seminars were presented and discussed and the existing and future challenges for the market was mapped out.

Latvia hosted the third meeting on 24 January 2005. At the meeting a draft report was discussed - including a broad range of proposals which could possibly be included in a future common Nordic-Baltic application for the Promotion-scheme.

\footnotetext{
${ }^{2}$ SWOT: Strengths, Weaknesses, Opportunities and Threats
} 
Based on the meeting in Latvia the final report was drawn up and agreed upon by the involved parties.

\subsection{Readers Guide to the Content of the Report}

The remaining part of this report is structured as follows:

\section{Chapter 2: The organic market in the Nordic/Baltic region}

This chapter establishes an overview of the organic food market in the Nordic/Baltic region. Collecting the data has caused some difficulties, since no standardised methods exist. Although the data are not completely compatible, comparison is attempted within the areas of: Primary production, processing, marketing channels, consumption pattern, imports/exports and organic control.

\section{Chapter 3: Barriers for further Development of the Organic Market}

This chapter will describe the barriers for the organic market which were identified during the national seminars and at the Steering Committee meeting held in Helsinki in November 2004.

The identified barriers are structured in the headlines: Consumer awareness and trust, deficient market transparency, standards and labelling, lack of marketing channels, lack of processing and innovation, high prices.

\section{Chapter 4: Conditions for Funding through the Promotion Scheme}

Having identified the Promotion scheme as the most appropriate funding opportunity for a regional project aiming at the market with a generic approach, this chapter will outline the conditions in the regulation, which will have to be met to secure the acceptance of the application.

The description of the promotion scheme will address issues such as: Deadlines, project partners, applicants, implementing participants, national co-funding demands, etc. The various conditions will be supplemented with experiences to the extent they are available

\section{Chapter 5: Potential Project Activities}

The chapter will list potential project activities. They are listed according to three criteria;

1) Compliance with barriers described in chapter 3 ,

2) Fall within the framework conditions of the Promotion scheme,

3) Be suitable for regional initiatives across borders.

They will all be oriented towards the development of the organic market according to the overall scope of this project. 


\section{Chapter 6: From idea to action}

The chapter will entail the conclusions agreed upon during the final Steering Committee meeting 23-24 January in Jelgava, Latvia. The participants had to clarify which project elements from chapter 5 each member could express an interest in and their national possibilities of cofinancing. 


\section{The Organic Market in the Nordic-Baltic Region}

The Nordic/Baltic region covers great differences in organic production, due to a series of factors, such as structural and economic development, consumption patterns, preferences and regulatory environment.

As a consequence the maturity of the organic markets varies a great deal in the Nordic/Baltic region.

The aim of this chapter is to display in more detail the similarities and differences within the Nordic/Baltic region. This will be attempted through different tables. Collecting the data has been difficult despite the great help provided for by the members of the Steering Committee. Many data are still missing and those available stems from different sources. As a consequence they do not represent a standardised methodology. Although the data are not completely compatible and differ in reference year, comparison is attempted within the areas of:

- Primary production

- Processing

- Marketing channels

- Consumption pattern

- Import/Export

- Organic control

The first table is a quick attempt to establish the importance of agricultural production in relation to the socio-economic context of the countries in the Nordic/Baltic region. The parameters chosen are agriculture's share of the gross domestic product and the employed labour force. The last row on the right display organic products' market share.

Table 1: Agriculture in the Nordic/Baltic countries

\begin{tabular}{|l|r|r|r|}
\hline & $\begin{array}{r}\text { Agriculture's share of } \\
\text { gross domestic product }\end{array}$ & $\begin{array}{r}\text { Agriculture's share of the } \\
\text { employed labour force }\end{array}$ & $\begin{array}{r}\text { Total market share for } \\
\text { organic products }\end{array}$ \\
\hline Denmark (2004) & $3 \%$ & $3 \%$ & $3,5 \%^{3}$ \\
\hline Estonia (2003) & $2,6 \%$ & $5,8 \%$ & ${ }^{*}$ \\
\hline Finland (2000) & $1,1 \%$ & $5 \%$ & ${ }^{*}$ \\
\hline Latvia (2004) & $7,1 \%$ & $16,5 \%$ & $<1,5 \%$ \\
\hline Lithuania (2004) & $7,1 \%$ & $16,5 \%$ & $<1 \%{ }^{4}$ \\
\hline Norway & $0,7 \%$ & $3,6 \%$ & $2,5 \%{ }^{4}$ \\
\hline Sweden (2004) & $0,6 \%$ & $1,8 \%$ & \\
\hline
\end{tabular}

No available data

\footnotetext{
${ }^{3}$ Statistics Denmark, 2003

${ }^{4}$ Organic Monitor, 2003
} 
Especially Latvia and Lithuania differ from the remaining countries listed in the table because of agriculture's relatively high contribution to the GDP and a high share of the labour force employed within agricultural production ${ }^{5}$.

Denmark is the country where organic products has the biggest market share with 3,5\%. In Sweden 2,5\% of the total market share is covered by organic products.

\subsection{Production}

This section addresses four types of data to illustrate the extend of organic production;

1) organic production compared with conventional production from 1998

-2002 ,

2) number of organic farms,

3 ) the most popular crops, and

4) livestock production.

Table 2: Organic area $1998-2004$

\begin{tabular}{|c|c|c|c|c|c|c|c|}
\hline $\begin{array}{l}\text { Organic } \\
\text { Produc- } \\
\text { tion } \\
(1000 \text { ha) }\end{array}$ & 1998 & 1999 & 2000 & 2001 & 2002 & 2003 & 2004 \\
\hline Denmark & $\begin{array}{c}99 \\
(3,7 \%)\end{array}$ & $\begin{array}{c}147 \\
(5,5 \%)\end{array}$ & $\begin{array}{c}165 \\
(6,2 \%)\end{array}$ & $\begin{array}{c}172 \\
(6,5 \%)\end{array}$ & $\begin{array}{c}178 \\
(7 \%)\end{array}$ & $\begin{array}{c}168 \\
(6,3 \%)\end{array}$ & 160 \\
\hline Estonia & $\begin{array}{c}3 \\
(0,3 \%)\end{array}$ & $\begin{array}{c}4 \\
(0,4 \%)\end{array}$ & $\begin{array}{c}10 \\
(1,0 \%)\end{array}$ & $\begin{array}{c}20 \\
(2,3 \%)\end{array}$ & $\begin{array}{c}31 \\
(3,5 \%)\end{array}$ & $\begin{array}{c}43 \\
(4,9 \%)\end{array}$ & $\begin{array}{c}46 \\
(5,3 \%)\end{array}$ \\
\hline Finland & $\begin{array}{c}126 \\
(5,8 \%)\end{array}$ & $\begin{array}{c}137 \\
(6,2 \%)\end{array}$ & $\begin{array}{c}147 \\
(6,7 \%)\end{array}$ & $\begin{array}{c}148 \\
(6,6 \%)\end{array}$ & $\begin{array}{c}157 \\
(7,0 \%)\end{array}$ & $\begin{array}{c}160 \\
(7,2 \%)\end{array}$ & $\begin{array}{c}\text { estima- } \\
\text { ted } 169 \\
(7,6 \%)\end{array}$ \\
\hline Latvia & $\begin{array}{c}1 \\
(0,1 \%)\end{array}$ & $\begin{array}{c}2 \\
(0,15 \%)\end{array}$ & $\begin{array}{c}4 \\
(0,17 \%)\end{array}$ & $\begin{array}{c}11 \\
(0,57 \%)\end{array}$ & $\begin{array}{c}17 \\
(0,68 \%)\end{array}$ & $\begin{array}{c}24 \\
(1,4 \%)\end{array}$ & $\begin{array}{c}44 \\
(1,9 \%)\end{array}$ \\
\hline Lithuania & 4 & 4 & 5 & 6 & $\begin{array}{c}9 \\
(0,25 \%)\end{array}$ & $\begin{array}{c}23 \\
(1 \%)\end{array}$ & 43 \\
\hline Norway & $\begin{array}{c}15 \\
(1,5 \%)\end{array}$ & $\begin{array}{c}19 \\
(1,8 \%)\end{array}$ & $\begin{array}{c}21 \\
(2,0 \%)\end{array}$ & $\begin{array}{c}27 \\
(2,8 \%)\end{array}$ & $\begin{array}{c}33 \\
(3,3 \%)\end{array}$ & $\begin{array}{c}38 \\
(3,7 \%)\end{array}$ & $\begin{array}{c}41 \\
(3,9 \%)\end{array}$ \\
\hline Sweden & 127 & 156 & 172 & 155 & 183 & $\begin{array}{c}226 \\
(7,1 \%)\end{array}$ & * \\
\hline
\end{tabular}

The numbers for organic farming includes the area under conversion

$(\%)$ : Organic area as share of total agricultural area in hectare

* No available data

Sweden, Denmark and Finland are the three countries with the largest organically produced areas. Especially Sweden seem to experience a

\footnotetext{
${ }^{5}$ It is uncertain whether the share of employment include people working in the secondary sector of the agricultural production, such as industries processing raw material from primary production.
} 
growth in conversion of agricultural land to organic, while Denmark have had a minor decrease during the last year.

Latvia have increased their share of land converted to organic production 44 times. This is the largest increase in the table although from a very low point of departure.

Latvia and Lithuania have the lowest share of their total farmland being cultivated as organic. Estonia places itself in the middle with a relatively high percentage of organically cultured farmland. The country has increased organic cultivation 15 times from 1998-2004.

Table 3: Organic Farms in the Nordic/Baltic Countries (Total and \% of all farms)

\begin{tabular}{|c|c|c|c|c|c|c|c|}
\hline $\begin{array}{l}\text { Organic } \\
\text { farms/year }\end{array}$ & 1998 & 1999 & 2000 & 2001 & 2002 & 2003 & 2004 \\
\hline Denmark & $\begin{array}{c}2.228 \\
(3,5 \%)\end{array}$ & $\begin{array}{c}3.099 \\
(5,2 \%)\end{array}$ & $\begin{array}{l}3.466 \\
(6,4 \%)\end{array}$ & $\begin{array}{l}3.525 \\
(6,5 \%)\end{array}$ & $\begin{array}{c}3.714 \\
(7,3 \%)\end{array}$ & $\begin{array}{c}3.510 \\
(6,5 \%)\end{array}$ & 3.166 \\
\hline Estonia & $\begin{array}{c}76 \\
(0,08 \%)\end{array}$ & $\begin{array}{c}89 \\
(0,1 \%)\end{array}$ & $\begin{array}{c}230 \\
(0,3 \%)\end{array}$ & $\begin{array}{c}369 \\
(0,5 \%)\end{array}$ & $\begin{array}{c}583 \\
(0,8 \%)\end{array}$ & $\begin{array}{c}764 \\
(1,1 \%)\end{array}$ & $\begin{array}{c}810 \\
(1,2 \%)\end{array}$ \\
\hline Finland & $\begin{array}{c}4.975 \\
(5,5 \%)\end{array}$ & $\begin{array}{c}5.197 \\
(5,9 \%)\end{array}$ & $\begin{array}{l}5.225 \\
(6,5 \%)\end{array}$ & $\begin{array}{l}4.983 \\
(6,4 \%)\end{array}$ & $\begin{array}{l}5.071 \\
(6,8 \%)\end{array}$ & $\begin{array}{l}4.983 \\
(6,6 \%)\end{array}$ & $\begin{array}{l}4.924 \\
(6,9 \%)\end{array}$ \\
\hline Latvia & 39 & 63 & 78 & 219 & 352 & 550 & 1.043 \\
\hline Lithuania & 144 & 171 & 230 & 293 & 393 & 700 & 1.178 \\
\hline Norway & $\begin{array}{c}1.589 \\
(2,3 \%)\end{array}$ & 1.745 & 1.745 & 2.099 & 2.303 & 2.466 & 2.482 \\
\hline Sweden & 2.870 & 3.253 & 3.329 & 3.589 & $\begin{array}{l}5.268 \\
(6,5 \%)\end{array}$ & 3.400 & * \\
\hline
\end{tabular}

( ) $\%$ of all farms

* No data available

Despite being an absolute figure, the number of organic farms is a difficult data to compare due to great variation in the size of land cultivated.

Latvia have increased their number of organic farms 27 times from 1998-2004.

\subsubsection{Organic Crops in the Nordic/Baltic countries}

The largest areas used for different organic crops have been included in the table below. The aim is to display the production capacity utilised for the most widespread organic crops in various categories. That means that some crops do not appear in Table 5 although they are being produced, but have been left out due to their lack of quantity. 
Table 4: Distribution of Organic Crops in the Nordic/Baltic Region

\begin{tabular}{|c|c|c|c|c|c|c|c|}
\hline Crops & $\begin{array}{r}\text { Denmark } \\
(2003)\end{array}$ & $\begin{array}{r}\text { Estonia } \\
(2003)\end{array}$ & $\begin{array}{r}\text { Finland } \\
(2003)\end{array}$ & $\begin{array}{l}\text { Latvia } \\
(2002)\end{array}$ & $\begin{array}{r}\text { Lithuania } \\
(2002)\end{array}$ & $\begin{array}{r}\text { Norway } \\
(2003)\end{array}$ & $\begin{array}{l}\text { Swedeg } \\
(1999)\end{array}$ \\
\hline Fallow & $2,8 \%$ & $4 \%$ & $9,5 \%$ & * & $9,2 \%$ & - & $21 \%$ \\
\hline Grassland & $32 \%$ & $76 \%$ & $8,7 \%$ & $70 \%$ & $46,4 \%$ & $85 \%$ & $41 \%$ \\
\hline $\begin{array}{l}\text { Vegetables and } \\
\text { potatoes }\end{array}$ & $1,3 \%$ & $1 \%$ & $5,4 \%^{7}$ & $2 \%$ & $2,1 \%$ & $1,6 \%$ & $1,0 \%$ \\
\hline $\begin{array}{l}\text { Fodder } \\
\text { cereals, and Pulses }\end{array}$ & $10,5 \%$ & $13 \%$ & $41,8 \%$ & $19 \%$ & $25,2 \%$ & $13,5 \%$ & $36 \%$ \\
\hline Bread Cereals/grain & $32,3 \%$ & $* *$ & $6,5 \%$ & $5,7 \%$ & $* *$ & ** & - \\
\hline Horticultural Crops & $17,5 \%$ & - & $3 \%^{8}$ & - & * & - & - \\
\hline Berries and fruits & $0,2 \%$ & $1 \%$ & $13,2 \%$ & $3 \%$ & $5,4 \%$ & $0,3 \%$ & - \\
\hline Others & $3,5 \%$ & $5 \%^{9}$ & $11,9 \%$ & $0,3 \%$ & 11,7 & $0,5 \%$ & $1,0 \%$ \\
\hline
\end{tabular}

* : No data available

**: No distinction between fodder cereals and bread cereals in the statistics used for the table.

Grassland is the crop covering the largest area in most countries in the region, except for Finland, where fodder cereals and pulses holds the largest share $(41,8 \%)$. It is also the second largest crop in the rest of the countries in the survey (between 13-36\%). Denmark being the only exception, due to bread cereals/grains being the other dominant crop. This picture is displayed in absolute terms in the following table.

\subsubsection{Organic Livestock}

Table 5: Organic Livestock Production / Year

\begin{tabular}{|c|c|c|c|c|c|c|c|}
\hline $\begin{array}{l}\text { Production } \\
\text { Line }\end{array}$ & $\begin{array}{r}\text { Denmark } \\
(2003)\end{array}$ & $\begin{array}{r}\text { Estonia } \\
(2003)\end{array}$ & $\begin{array}{r}\text { Finland } \\
(2003)\end{array}$ & $\begin{array}{l}\text { Latvia } \\
(2004)\end{array}$ & Lithuania & $\begin{array}{r}\text { Norway } \\
(2003)\end{array}$ & $\begin{array}{r}\text { Sweden } \\
(2003)\end{array}$ \\
\hline $\begin{array}{l}\text { Milking } \\
\text { cows }\end{array}$ & $\begin{array}{r}56.430 \\
(16,4 \%)\end{array}$ & $\begin{array}{r}2.484 \\
(2,0 \%)\end{array}$ & 4.990 & 2.415 & * & 5.226 & 22.215 \\
\hline $\begin{array}{l}\text { Pieces of } \\
\text { cattle }\end{array}$ & $\begin{array}{r}67.981 \\
(21,5 \%)\end{array}$ & $\begin{array}{r}1.753 \\
\left(^{*}\right)\end{array}$ & 8.853 & 624 & * & 10.237 & 70.086 \\
\hline $\begin{array}{l}\text { No. of } \\
\text { lambs }\end{array}$ & & 2.685 & * & - & * & 30.413 & 24.056 \\
\hline Sheep & $\begin{array}{l}12.530 \\
(6,0 \%)\end{array}$ & 3.031 & 3.386 & 89 & * & & 16.537 \\
\hline Poultry & $\begin{array}{r}1.179 .060 \\
(8,2 \%)\end{array}$ & $\begin{array}{r}3.388 \\
(0,2 \%)\end{array}$ & & 4.069 & & 45.931 & \\
\hline $\begin{array}{r}\text { - Laying } \\
\text { hens }\end{array}$ & 792.494 & 3.043 & 75.120 & & & 38.628 & 321.955 \\
\hline - Broilers & 364.575 & 67 & 0 & & & 6.115 & 21.600 \\
\hline - Turkeys & 8.995 & 4 & 17 & & & 840 & \\
\hline - others & 2.915 & 274 & 14 & & & 4 & \\
\hline $\begin{array}{l}\text { No. of } \\
\text { pigs }\end{array}$ & 73.791 & $\begin{array}{r}448 \\
(0,1 \%)\end{array}$ & 2.628 & 1.714 & * & 505 & 22.134 \\
\hline $\begin{array}{l}\text { Bee } \\
\text { keeping } \\
\text { (colonies) }\end{array}$ & - & $323(1 \%)$ & 1.190 & 2.366 & * & 181 & * \\
\hline
\end{tabular}

() indicate animals in organic production as $\%$ of total production * No data available

\footnotetext{
${ }^{6}$ Preliminary figures

${ }^{7}$ Vegetables and potatoes grown in the open, total

${ }^{8}$ Vegetables grown in greenhouses, total

${ }^{9} 4 \%$ cover unused agricultural land
} 
Denmark is the country with the largest livestock production, except for sheep, goats, lambs and beef. Sweden have the largest number of cattle, lamb and sheep, while they have the second largest livestock production when looking at the remaining types of livestock.

\subsection{Processing}

Table 6: Processing Companies

\begin{tabular}{|c|c|c|}
\hline & $\begin{array}{l}\text { Registered } \\
\text { companies }\end{array}$ & Types of companies \\
\hline $\begin{array}{l}\text { Denmark } \\
(2004)^{10}\end{array}$ & 580 & $\begin{array}{l}\text { Retail (restaurants, bakery sale, shops, green grocery, canteen, } \\
\text { pharmacy) } 27,5 \% \\
\text { Bakeries } 5,6 \% \\
\text { Slaughterhouses, cutting and wholesale of meat } 14,6 \% \\
\text { Wholesale } 14,1 \% \\
\text { Dairies } 8,5 \% \\
\text { Breweries } 1,5 \% \\
\text { Fruit/vegetable packaging and processing } 14,4 \% \\
\text { Eggs } 3,1 \% \\
\text { Farm processing } 0,5 \% \\
\text { Others } 10,2 \%\end{array}$ \\
\hline $\begin{array}{l}\text { Estonia } \\
\text { (2004) }\end{array}$ & 6 & $\begin{array}{l}\text { Packaging of crop seed } \\
\text { Packaging of vegetables and fruits } \\
\text { Slaughterhouse } \\
\text { Pressing of oil }\end{array}$ \\
\hline $\begin{array}{l}\text { Finland } \\
(2004)^{11}\end{array}$ & 436 & $\begin{array}{l}\text { Preparation of food products on farm } 19 \% \\
\text { Mill } 10 \% \\
\text { Bakery } 11 \% \\
\text { Manufacture of other food products } 19 \% \\
\text { Packaging } 10 \% \\
\text { Importer and manufacture } 3 \% \\
\text { Collecting and trading of wild berries and plants } 2 \% \\
\text { Food products of animal origin } 18 \% \\
\text { Contractor } 3 \% \\
\text { Other } 5 \%\end{array}$ \\
\hline Latvia & 6 & $\begin{array}{l}2 \text { Bakeries } \\
1 \text { small slaughterhouse } \\
2 \text { small milking factories } \\
1 \text { tea drying factory }\end{array}$ \\
\hline $\begin{array}{l}\text { Lithuania } \\
\text { (2003) }\end{array}$ & 20 & $\begin{array}{l}\text { Mills } \\
\text { Bakery } \\
\text { Dairy } \\
\text { Mushroom and frozen fruit processing } \\
\text { Dried herbs } \\
\text { Juice } \\
\text { Canned vegetables }\end{array}$ \\
\hline $\begin{array}{l}\text { Norway } \\
(2003)\end{array}$ & 344 & $\begin{array}{l}\text { Dairies }(5,5 \%) \\
\text { Slaughterhouse }(10,5 \%) \\
\text { Bakeries }(5,8 \%) \\
\text { Mills }(9,6 \%) \\
\text { Catering }(2 \%) \\
\text { Farm processing }(18,3 \%) \\
\text { Wholesalers }(3,8 \%) \\
\text { Convenience chains }(22.7 \%) \\
\text { Other processors, packers and importers }(21,2 \%)\end{array}$ \\
\hline $\begin{array}{l}\text { Sweden } \\
(2000)\end{array}$ & 482 & $\begin{array}{l}\text { Diary } \\
\text { Slaughterhouse } \\
\text { Bakeries } \\
\text { Mills } \\
\text { Farm processing } \\
\text { Other processors }\end{array}$ \\
\hline
\end{tabular}

\footnotetext{
${ }^{10}$ Danish Veterinary and Food Administration

${ }^{11}$ Source: National Food Agency Finland
} 
Processors include market operators that preserve, process, package and label organic products. Some differences between definition prevail. In Denmark for instance, retailing companies are also registered if they have a permit to process organic foods. The registered companies include companies that both process organic and conventional products. Furthermore, the processors can be registered as one sort of company, while their activity encompassing the organic products can belong to another category. This means, that some insecurity is linked to the figures presented here. Another distorting aspect is the known fact that not every registered company is active as a processors.

The processors size ranges from small to large enterprises. This gives an additional reservation to the absolute numbers of processing companies, since the number does not reflect the degree of product development.

\subsection{Retailers}

Table 7: Retail Channels for Organic Sales ( $\%$ of the total organic turnover)

\begin{tabular}{|c|c|c|c|c|c|c|}
\hline & $\begin{array}{r}\text { Speciali- } \\
\text { sed shops }\end{array}$ & $\begin{array}{r}\text { Supermar- } \\
\text { kets }\end{array}$ & $\begin{array}{r}\text { Whole } \\
\text { sale } \\
\text { traders }\end{array}$ & $\begin{array}{r}\text { Local } \\
\text { market } \\
\text { places }\end{array}$ & $\begin{array}{r}\text { Farmgate } \\
\text { sales }\end{array}$ & $\begin{array}{r}\text { Box } \\
\text { schemes }\end{array}$ \\
\hline Denmark & $6 \%$ & $81 \%$ & & $1 \%$ & $4 \%$ & $8 \%$ \\
\hline Estonia & * & * & * & * & * & * \\
\hline Finland $^{12}(2004)$ & * & $88 \%$ & * & * & * & * \\
\hline Latvia & $10 \%$ & $5 \%$ & & $35 \%$ & $50 \%$ & \\
\hline Lithuania $^{13}$ & $5 \%$ & $10 \%$ & * & $30 \%$ & $5 \%$ & * \\
\hline Norway & * & $90 \%$ & * & * & * & * \\
\hline Sweden ${ }^{14}$ & * & $73 \%$ & * & * & $7 \%$ & * \\
\hline
\end{tabular}

* No data available

The maturity of the markets in respectively the Baltic and the Nordic region is reflected in the distribution pattern. The more mature organic markets in the Nordic countries is characterised by selling the largest share of organic products in supermarkets. The Baltic countries have the opposite distribution pattern. Their organic sales is primarily through local market places and organic farm sales.

\footnotetext{
${ }^{12}$ Information on the retail channel for organic sales in Finland, Norway and Sweden does not add up to the entire $100 \%$ for all organic sales.

${ }^{13}$ Preliminary estimation made by Emilija Kairyte, Lithuanian Institute of Agrarian Economics.

${ }^{14}$ Hamm et al, 2002 and FiBL 2003.
} 


\subsection{Consumption Pattern}

Table 8: Consumers buying Organic Products

\begin{tabular}{lrrr}
\hline $\begin{array}{l}\text { Consumption } \\
\text { pattern }\end{array}$ & Buy organic Regularly & Buy organic occasionally & Never buy organic \\
\hline Denmark ${ }^{15}(2002)$ & $40 \%$ & $55 \%^{16}$ & $5 \%$ \\
Estonia & $*$ & $41 \%$ & $*$ \\
Finland $(2004)^{17}$ & $22 \%$ & $91 \%{ }^{18}$ & $36 \%$ \\
Latvia & $*$ & $56 \%{ }^{2}$ & $9 \%$ \\
Lithuania & $14 \%$ & $48 \%$ & $30 \%$ \\
Norway & $6 \%$ & & $45 \%$ \\
Sweden & & $*$ \\
\hline
\end{tabular}

* No data available

The data in this table are difficult to compare, since their methodological approach differs a great deal. This underline two things; firstly, the need to collect more data on the demand side to get to know consumption patterns better, and secondly, the need to agree on a common approach to collection of statistical data

Concluding on the data from Latvia should be done with some precaution, since the data is based on express of interest from consumers. Research shows that the intention to act a certain way does not necessarily comply with real actions.

\subsection{Import/Export of Organic Products}

The following tables only cover the countries that could provide data. It is important to note that the percentages given for the different organic food categories is respectively imports share of the total organic market and exports share of total production.

Table 9: Import/export - Norway ${ }^{20}$

\begin{tabular}{|c|c|c|c|c|c|c|c|}
\hline & $\begin{array}{r}\text { Meat } \\
\text { and } \\
\text { charcu- } \\
\text { terie }\end{array}$ & $\begin{array}{r}\text { Fruits } \\
\text { and } \\
\text { Vege- } \\
\text { tables }\end{array}$ & Cereals & $\begin{array}{r}\text { Bakery } \\
\text { pro- } \\
\text { ducts }\end{array}$ & $\begin{array}{l}\text { Dairy } \\
\text { pro- } \\
\text { ducts }\end{array}$ & $\begin{array}{l}\text { Non- } \\
\text { dairy } \\
\text { drinks }\end{array}$ & Eggs \\
\hline $\begin{array}{l}\text { Imports }\left({ }^{*} €\right)(\% \text { of } \\
\text { organic market) }\end{array}$ & $0 \%$ & $35 \%$ & $65 \%$ & $0 \%$ & $5 \%$ & $98 \%$ & $0 \%$ \\
\hline $\begin{array}{l}\text { Exports }(2,15 \text { mill. } € \text { ) } \\
\text { (\% of total organic } \\
\text { production) }\end{array}$ & $0 \%$ & $0 \%$ & $0 \%$ & $0 \%$ & $0 \%$ & $0 \%$ & $0 \%$ \\
\hline
\end{tabular}

\footnotetext{
${ }^{15}$ Source: Gfk ConsumerScan 2002

${ }^{16}$ Consumers spending up to $2,5 \%$ of their food budget on organic produce

${ }^{17} \mathrm{Finfood} /$ Consumer barometer 9/2004

${ }^{18}$ Percentage of population expressing interest in purchase of organic products

${ }^{19}$ The percentage is an assumption based on the distinction between the organic consumer $(6 \%)$ and consumers that have never bought organic food $(30 \%)$.

${ }^{20}$ Organic Monitor, 2003
} 
Except for meat, bakery and non-diary drink products, Norway is a netimporter of organic products sold on the market.

Table 5: Import/export - Sweden ${ }^{20}$

\begin{tabular}{lcccccc}
\hline & $\begin{array}{c}\text { Meat and } \\
\text { charcute- } \\
\text { rie }\end{array}$ & $\begin{array}{r}\text { Fruits and } \\
\text { Vege- } \\
\text { tables }\end{array}$ & Cereals & $\begin{array}{r}\text { Bakery } \\
\text { products }\end{array}$ & $\begin{array}{r}\text { Dairy } \\
\text { products }\end{array}$ & $\begin{array}{r}\text { Non-dairy } \\
\text { drinks }\end{array}$ \\
\hline $\begin{array}{l}\text { Imports }\left({ }^{*} €\right) \% \text { of } \\
\text { organic market }\end{array}$ & $2 \%$ & $33 \%$ & $18 \%$ & $0 \%$ & $5 \%$ & $20 \%$ \\
$\begin{array}{l}\text { Exports }(6,71 \text { mill. } \\
\begin{array}{l}€(\% \text { of total } \\
\text { organic production) }\end{array}\end{array}$ & $0 \%$ & $0 \%$ & $0 \%$ & $0 \%$ & $0 \%$ & $48 \%$ \\
\hline
\end{tabular}

Except for bakery products and non-diary drinks, Sweden is a netimporter of all of the organic products sold in their market.

\begin{tabular}{|c|c|c|c|c|c|c|}
\hline & $\begin{array}{r}\text { Meat and } \\
\text { charcute- } \\
\text { rie }\end{array}$ & $\begin{array}{r}\text { Fruits and } \\
\text { Vege- } \\
\text { tables }\end{array}$ & Cereals & $\begin{array}{r}\text { Bakery } \\
\text { products }\end{array}$ & $\begin{array}{r}\text { Dairy } \\
\text { products }\end{array}$ & $\begin{array}{r}\text { Non-dairy } \\
\text { drinks }\end{array}$ \\
\hline $\begin{array}{l}\text { Imports }\left({ }^{*} €\right) \% \text { of } \\
\text { organic market }\end{array}$ & $0 \%$ & $35 \%$ & $20 \%$ & $0 \%$ & $5 \%$ & $98 \%$ \\
\hline $\begin{array}{l}\text { Exports ( } 1,34 \text { mill. } \\
€)(\% \text { of total } \\
\text { organic production) }\end{array}$ & $0 \%$ & $0 \%$ & $45 \%$ & $0 \%$ & $0 \%$ & $0 \%$ \\
\hline
\end{tabular}

Table 7: Import/Export - Estonia ${ }^{21}$

\begin{tabular}{|c|c|c|c|c|c|c|c|}
\hline & $\begin{array}{r}\text { Meat } \\
\text { and } \\
\text { char- } \\
\text { cuterie }\end{array}$ & $\begin{array}{r}\text { Fruits } \\
\text { and } \\
\text { Vege- } \\
\text { tables }\end{array}$ & Cereals & $\begin{array}{r}\text { Bakery } \\
\text { pro- } \\
\text { ducts }\end{array}$ & $\begin{array}{r}\text { Dairy } \\
\text { pro- } \\
\text { ducts }\end{array}$ & $\begin{array}{l}\text { Non- } \\
\text { dairy } \\
\text { drinks }\end{array}$ & Eggs \\
\hline $\begin{array}{l}\text { Imports (\% of } \\
\text { organic market) }\end{array}$ & None & None & None & None & None & None & None \\
\hline $\begin{array}{l}\text { Exports ( } \% \text { of total } \\
\text { organic produc- } \\
\text { tion) }\end{array}$ & None & None & None & None & None & None & None \\
\hline
\end{tabular}

According to table 16, Estonia is not involved in any cross-boarder trading with organic products despite a considerable production.

Table 8: Imports/Exports - Denmark (in absolute figures) ${ }^{22}$

\begin{tabular}{lllllll}
\hline & $\begin{array}{l}\text { Meat and } \\
\text { char- } \\
\text { cuterie }\end{array}$ & $\begin{array}{l}\text { Fruits and } \\
\text { Vege- } \\
\text { tables }\end{array}$ & Cereals & $\begin{array}{l}\text { Bakery } \\
\text { products } \\
\text { and eggs }\end{array}$ & $\begin{array}{l}\text { Dairy } \\
\text { products }\end{array}$ & $\begin{array}{l}\text { Non-diary } \\
\text { drinks }\end{array}$ \\
\hline Imports (mill. $€$ ) & - & 12,7 mill. & 6,8 mill. & - & 0,5 mill. & 0,9 mill. \\
Exports (mill. $€$ ) & 4,6 mill. & 3,8 mill. & 3,3 mill. & - & 9,6 mill. & 0,2 mill. \\
\hline
\end{tabular}

\footnotetext{
${ }^{21}$ Source: Margot Pomerants, Head of Bureau of Organic Farming, Ministry of Agriculture, Estonia

${ }^{22}$ Source: Danmarks Statistik, nr. $511-292003$
} 
It should be noted that the units displayed in the Danish table differs from the previous ones in this subsection.

In 2003 Denmark had a net import of organic products, with imports worth of 37,3 mill. $€$ and exports worth 31 mill. $€$. There were big differences between the composition of products when comparing the import and export of organic products.

Fruits and vegetables constitute $34 \%$ of the total imports, followed by cereals $(18 \%)$ and coffee, tea cocoa, chocolate and spices (12\%).

The Danish export is dominated by processed products, while the opposite is the case for the import. Dairy products and eggs constitute $31 \%$ of the total export, followed by meats and charcuterie $(15 \%)$.

\subsection{Organic Control}

The table below contains the distribution between National inspection authorities and private organisation inspections. Although the national authorities in some cases organise the inspection, the collected data are in some countries, e.g. Finland, used by private organisations who have their own organic standards.

Table 9: National and private inspection/standards

\begin{tabular}{lcccc}
\hline & $\begin{array}{c}\text { National Inspec- } \\
\text { tion Authorities }\end{array}$ & $\begin{array}{c}\text { National Stan- } \\
\text { dards }\end{array}$ & $\begin{array}{c}\text { Private Inspec- } \\
\text { tion }\end{array}$ & $\begin{array}{c}\text { Private Stan- } \\
\text { dards }\end{array}$ \\
\hline Denmark & $\mathrm{X}$ & $\mathrm{X}$ & & \\
Estonia $^{23}$ & $\mathrm{X}$ & $\mathrm{X}^{24}$ & & \\
Finland & $\mathrm{X}$ & $\mathrm{X}$ & $\mathrm{X}$ & $\mathrm{X}$ \\
Latvia & $\mathrm{X}$ & $\mathrm{X}$ & & $\mathrm{X}$ \\
Lithuania & $\mathrm{X}$ & $\mathrm{X}$ & $\mathrm{X}$ \\
Norway & & $\mathrm{X}$ & $\mathrm{X}$ \\
Sweden & & & & \\
\hline
\end{tabular}

\subsection{Conclusion}

The data displayed has shown the great variety in organic production, processing and sales within the Nordic Baltic region. There is a clear gap between the level of development of the organic sector within the Nordic and the Baltic countries, the latter being the least developed. Both in terms of share of farmland used for organic farming and maturity of the organic market. In the Baltic countries practically no processing companies exists. Neither does import of organic products. Moreover organic sales mainly takes place through stable sales and market places.

\footnotetext{
${ }^{23}$ In Estonia a state register of Organic agriculture where established in 2001. It contains contact data for all primary producers and is accessible to the public. The purpose is to collect information for inspection and secure reliability of the organic production.

${ }^{24}$ According to EU regulation, national law.
} 
The Baltic countries experiences a large growth in the share of farmland being grown organically, although coming from a very low base.

Data concerning the market share of organic products are completely missing from the Baltic countries. 


\section{Barriers for Further Development of the Organic Market}

This chapter describes the barriers for the further development of the organic market in the Nordic-Baltic region.

The identified barriers have been divided in clusters in order to structure their description. The chronology of the clusters do not reflect a hierarchy of importance.

\subsection{Consumer awareness}

Increase in sales is depending on consumer awareness. If consumers are not aware of the attributes related to organic products their motivation to pay a higher price is difficult to establish and maintain.

Organic farming is based on additional requirements and restrictions in relation to:

- The use of pesticides

- The use of fertilisers

- Animal welfare

- Genetically modified organisms

- The use of additives

Lack of understanding of these parameters is regarded as a basic barrier for the development of the market for organic products. Market research show that only a limited (green) consumer-segment pay high attention to environmental parameters and that the main motivation for consuming organic products is related to health concerns and taste ${ }^{25}$. This is despite the fact that comparative research of nutritional aspects of conventional and organic food only to a very limited degree has been able to demonstrate any significant differences.

Raising public awareness on organic products through claims is a challenge due to the many exceptions that prevail within organic farming. It is not possible to make generic claims like "No use of pesticides", since

\footnotetext{
2004

${ }^{25}$ Commission Working Document, European Action Plan for Organic Food and Farming, June
} 
it is not valid for all organic crops, although the pesticides differ from the synthetic pesticides used in conventional production.

The organic sector is dependent on consumers trust. The control system and labelling of products constitute consumers guarantee that the products actually are produced in accordance with the regulations for organic production. Food scandals within the organic sector undermine consumer's trust in organic products actually being what they promise. Examples of minor food scandals have been higher dioxin content in organic eggs and illegal antibiotics found at organic stables. Examinations of eggs in Sweden and the Netherlands showed dioxin levels above EU-limiting values. Dioxin is a by-product of incinerated garbage and considered as one of the most hazardous hormone-disrupting chemicals. Even though the threat to health is caused by other activities in society, the image of organic food products is harmed. These cases brought in the media weakens the organic brands trustworthiness as being healthy, quality products worth paying extra money for. Another distinction within the issue of trust is in relation to the organic products as actually being better than conventional food.

\subsection{Deficient Market Data}

Being an infant industry, organic production and processing is characterised by relatively low volumes and a limited number of market operators. Also, the market operators are highly dependent on availability of market data - both as regards supply and demand.

However, due to limited development of official statistics, there is a lack of market data, which is also evident in chapter 2, where only few tables are displayed with market data. From a logic point of view this leads to higher prices and is therefore seen as a barrier to the further development of the organic market.

The producers cannot adjust their production according to the demand on the market and it is difficult for policy-makers to manoeuvre on a more strategic level in a long-term perspective.

\subsection{Standards and Labelling}

Development of both private and national rules and logos has been an important driving force for market development in the different countries. Even though organic production standards have been harmonised through EU-legislation, there are still great variations between the standards in the various Baltic/Nordic countries. Some of the countries only comply with 
the EU regulation ${ }^{26}$, which allow stricter national rules ${ }^{27}$ concerning animal production, while other countries have private inspection bodies with stricter requirements. Often, it is a very difficult task for producers, consumers and other interested parties to know exactly to what extent private and/or national official standards differentiate from each other and the EU-regulation. The lack of transparency between standards and rules can hamper the intra-Community trade within the organic sector.

Private labels and logos have been developed in all of the Baltic/Nordic countries. They all comply with the Council Regulation (EEC) No 2092/91. In principle, all products that are produced according to the requirements in the EU regulation can be marketed as organic in all $\mathrm{EU}$ countries. However, in many cases retailers will not market the products as organic if they do not bear the national/private label. One explanation is probably that the consumers will not be able to recognise the products as organic and therefore unwilling to pay the extra price. This type of practice works as a trade barrier. Re-labelling of imported goods is possible but expensive. In other cases special requirements concerning standards and inspection must be fulfilled in order to be able to label with the logos which also imply extra costs for foreign producers. Consequently, the competition is lowered and consumer prices remain high, which is identified as an additional barrier for increased sales.

\subsection{Lack of Marketing Channels}

Currently it seems that supermarkets experience the largest growth in organic sales in Europe $^{28}$. As Table 7: Retail Channels for Organic Sales display, supermarkets have the majority of the organic sale in the Nordic countries. Their share range from $81 \%$ to $90 \%$ of the organic sale.

A broad range of consumers have been confronted with organic products and been given the opportunity to buy them because of sale of organic products in supermarkets. Moreover, supermarkets have contributed to reduction in the price-gap between conventional and organic products due to efficient logistics.

However, consumers in supermarkets are often more price-sensitive. Supermarkets also constitute a barrier for the further development of the organic market given the continuous concentration within the retailingsector and their increased focus on large quantities, which cannot be met by the organic producers who mostly deliver small quantities.

Therefore it is crucial that organic products are marketed according to a pluralistic model, which would be in harmony with the principle of

\footnotetext{
${ }^{26}$ Council Regulation (EEC) No. 2092/91 of 24 June 1991 on organic production of agricultural products and indications referring thereto on agricultural products and foodstuffs.

${ }^{27}$ Article 12 in Council Regulation (EC) No. 2092/91 of 24 June 1991.

${ }^{28}$ Michelsen et al. : "The European Market for Organic Products: Growth and development", Series: Organic Farming in Europe: Economics and Policy Vollume 7
} 
subsidiarity. This means that more direct channels are important to develop the sale of organic products. It would also facilitate the communication due to the local context. Examples of such channels are direct gatesale from farmer to consumer, farmers markets and box schemes.

\subsection{Lack of Processing and Innovation}

Lack of innovation and product development is regarded as an important barrier to the development of the organic market. In some countries processed products are basically non-existent - leaving the organic consumers with a choice between a limited range of basic products. In other countries the organic market has reached a more mature status.

In the first case processing is needed - being highly dependent on improved market transparency as mentioned above in section 3.2.

In the case of mature markets, the organic sector needs to attract new consumer segments. The most interesting segment, often described as the blue segment, is not necessarily motivated by specific organic parameters - and if they are, their motivation might be rather brief. One day motivated by the organic story, another day by something completely different. In this situation innovation of high-quality products is needed, since high quality is a key issue regardless the market maturity and size in order to justify the higher prices for organic products.

\subsection{High Prices}

High prices are often identified as an obstacle to the growth of the organic food market, since they prevent many consumers from buying organic products. As mentioned earlier the trust in an actual value being created through organic production methods needs to be established to overcome the high prices as an obstacle for demand. But attempts to strike a balance between the perception of added value and lower prices should also be made.

Lowering prices could therefore be an important step to reach a better balance. Processors and retailers often receive a higher price premium ${ }^{29}$ when selling organic products. Therefore, they pose an opportunity for lowering of prices for the consumers and should be examined throughout the production and logistics chain. The EU average for consumer price premiums in 2001 varied from $28 \%$ for organic baby food in glass jars, up to $163 \%$ for organic cucumbers ${ }^{30}$. The study carried out within the

\footnotetext{
${ }^{29}$ The price premium is the additional percentage amount charged for organic products when compared with the price for the comparable conventional product. Source: "The European Market for Organic Food: Revised and Updated Analysis”, OMIaRD, vol. 5, 2004.

${ }^{30}$ Source: “The European Market for Organic Food: Revised and Updated Analysis”, OMIaRD, vol. 5
} 
framework of Organic Marketing Initiatives and Rural Development (OMIaRD) reached the conclusion that different sales channels within the EU plays an important role in differing price premiums between the countries. The report states that

"in countries where general food shops were very active in the marketing of organic food, consumer price premiums were generally lower than in those countries where organic food shops or direct sales provided the main sales channels",31

As listed in the European Action Plan (2004) the barriers encompass:

- higher purchase price of raw materials and problems with continuity of supply;

- higher costs for cleaning and separation in non-dedicated wholesale and processing units;

- lack of economies of scale (higher transport costs and small volumes of throughput leading to high distribution costs per unit);

- more unsold products and wastage;

- cost of inspection and certification;

- lower yield due to environmental considerations;

- higher animal welfare.

\footnotetext{
${ }^{31}$ Ibid., page VIII
} 


\section{The Promotion Scheme}

At the meeting in Finland the Steering Committee decided to focus on a single funding opportunity, the Promotion Scheme, rather than a broad range of different opportunities.

The reason for this were as follows:

- The Promotion scheme was seen as the single most relevant funding opportunity for the realisation of the ideas for future initiatives.

- The Steering Committee wanted to mature these ideas for future initiatives as much as possible. Tailoring these to a specific funding opportunity was therefore seen as productive and needed.

- By focussing on a single funding opportunity is was the hope not only to end the project by having a range of hypothetical initiatives - but also a clear platform for the process to follow, leading to one or more common Nordic-Baltic market initiatives.

Against this background this chapter outlines the conditions in the Promotion Scheme, which will have to be met to secure the acceptance of the application.

In formal terms the promotion scheme is known as: Commission Legislation (EC) 94/2002 of 18 January 2002 laying down detailed rules for applying the Council Regulation (EC) No 2826/2000 on information and promotion actions for agricultural products on the internal market. Both Regulations map out the rules for applying for funding. A recent update of the Council Regulation (No 2060/2004 of 22 November 2004) have resulted in some amendments of the legal framework. The detailed rules from the Commission on how to apply the Council Regulation still remains to be seen.

\subsection{Possible Organic Programmes}

The following headlines represents the content, which has to be included in a programme application. The supporting text under each headline covers the problems in focus for the scheme and which objectives the application has to comply with before being granted funding.

Be aware that the promotion scheme will be amended in the near future and that an up-dated version should therefore be requested from the relevant authority in your own country. 


\section{Overview of the Situation}

The consumption of organically produced agricultural products is particularly popular among urban populations, but it is still not well developed compared to the consumption of conventional products.

The knowledge of the special conditions for organic production methods is limited, although growing, among consumers and other interest groups.

In the European Action Plan for Organic Food and Farming, both promotion and information campaigns play an important role to trigger an increase in demand for organic products.

\section{Goals}

Rather than focussing on one or a few products, promotion and information campaigns should focus on groups of products or the organic production methods that are used in one or several regions or one or several Member States.

The objective of the campaign should be to:

- encourage the consumption of organic food products,

- make the labelling rules known to the public, including the EU-logo for organic products,

- provide extensive information on, and broaden the knowledge on the advantages of organic production in relation to protection of the environment, animal welfare, preservation of agricultural districts and development of the rural districts,

- provide extensive information about the EU regulation on organic production,

- urge primary producers and processors, who have not yet converted to organic production to do so and urge retailers and restaurants to sell organic products.

\section{Primary Target Groups}

- consumers in general, consumer associations and specific subgroups of consumers

- opinion formers

- interested parties/stakeholders in the foodstuff sector ( supermarkets, wholesalers, specialised retailers, catering business, canteens, restaurants and processing companies).

- teachers and schools

\section{Main Messages}

- Organic products are natural, suited to modern daily living and a pleasure to consume. They result from growing methods that respect the environment. The products are subject to stringent rules and they 
are checked for compliance by independent bodies and public authorities.

- The products are subjected to strict rules for the production and control. These include traceability to ensure that the that the products originate from farms that are subjected to an organic control system,

- The use of organic or biological wording, and equivalent words in other languages, for foodstuff is protected by law,

- The EU-logo constitutes the symbol for organic products, which is understood in the entire Community, indicate that the products comply with the strict criteria for production in the EU and have been subjected to strict control; information on the EU-logo can be supplemented with information on the logos introduced in the Member States,

- Other quality aspects (such as security, nutritive value, taste) of the products can be underlined.

5. Main Channels

- internet site,

- telephone information line,

- contacts with the media (e.g. specialised journalists, women's press),

- contacts with consumer associations,

- information at the point of sale

- events at schools

- Audio-visual media ( e.g. targeted TV-features)

- written documentation (leaflets, brochures, etc.).

- participation in fairs and expositions

- information, education and events about the application of EUlegislation for organic production and organic products.

6. Duration of the Programmes

12-36 months, giving priority to programmes that consist of a strategy and proper reasons for targets for every phase

7. Indicative Budget

EUR 3 million $^{32}$.

\subsection{Other Key-conditions to Bear in Mind}

Architecture of a programme

A programme consists of a variety of measures, which are extensive enough to contribute with an increased information about the products in question and lead to an increased sale.

\footnotetext{
${ }^{32}$ The 3 million Euro are for all organic activities within the promotion scheme.
} 
A programme can not be applied for AND implemented by the same body except for programmes where certain conditions apply. These exceptions still remain to be specified by the Commission in accordance with the latest legislative changes in the Council Legislation (EC) No. 2060/2004. The current rules implies that if for instance the programme is applied for by the Latvian Association of Organic Farmers, the Association is not allowed to act as the implementing body. A programme proposal must include all necessary documentation to assess the proposal. This include collecting three offers from different operators to document the competence of the selected implementing body.

Possibilities for non-EU partners to be involved

Non-EU partners can not apply for money within the Promotion scheme. This excludes Norway from receiving funding. The possibilities for Norway to participate without funding from EU should therefore be examined. Alternatively, funding for promotion in 3. countries is an option that might be interesting to explore further.

\section{Financing}

Within the Promotion scheme programmes can receive $50 \%$ funding from the European Commission. The remaining co-funding is restricted to the Member States (co-finance obligation $30 \%$ ) and the proposing organisation (co-finance obligation $20 \%$ ).

The payments made by Member States and/or the proposing organisations may come from parafiscal charges or compulsory contributions (Production Levy Funds).

The proposing organisation have to document the Member States' cofinancing of $30 \%$ of the actual programme costs. The documentation for the co-financing has to be available at the time of the programme application. The documentation must consist of a written acceptance from a Production Levy Fund, that the fund will support the programme financially. The budget for the total costs of the programme has to be specified in details without value added tax (VAT).

Details on national funding opportunities will follow.

More countries involved

When information and/or promotion programmes involve more than one Member State, the Member States concerned shall cooperate in drawing up compatible specifications and calls for proposals. The programme proposal has to be send to the competent body in each country involved.

Where more than one Member State contributes to financing, the share to be paid by each shall be proportionate to the financial contribution of the proposing organisation in its territory. 
Cash flow

The Commission can contribute with:

1. Year projects: $50 \%$ of the actual cost of measures under programmes lasting one year;

2. Year projects: $60 \%$ of the actual cost of measures during the first year and $40 \%$ during the second year. The total contribution from the Community must not exceed $50 \%$ of the total cost of the programme;

3. Year projects: : $60 \%$ of the actual cost of measures during the first year, $50 \%$ during the second year and $40 \%$ during the third year. The total contribution must not exceed $50 \%$ of the total cost of the programme.

The Member States will receive the money from the Commission. The Member state is responsible for the control of and payments to the programmes. The evaluation of the results of the sales drive and information campaign is beyond the responsibility of the Member State and has to be carried out by an impartial party.

\section{Contracts}

The results of the decision made by the Commission will be communicated to the proposing organisations by the Member State. Thereafter the Member State shall conclude contracts with the selected organisations within the following 30 calendar days. Beyond that deadline, no contracts may be concluded without prior authorisation from the Commission.

The Member States shall use standard forms of contract supplied by the Commission.

Deadlines

Check with national competent body in each country for deadlines.

\subsection{Inspiration from Previous Programmes}

\subsubsection{Austrian Promotion Campaign}

\section{Background}

The foodstuff crises generated by BSE and pigs plague during the last couple of years were the starting point for the Austrian campaign. The crisis situation was thought of as paving the way for an increase in sales of organic products. However, most Austrians know nothing or only little about the assets of organic farming. At the same time many consumers have doubts about the content of different organic labels. It is the aim of the campaign to increase the knowledge about organic farming and various organic labels. 
Objective and Measures

The Austrian image campaign for organic farming will communicate reasons for a conscious consumption of organic products while ensuring that the consumption gets deeply rooted to obtain a sustainable consumption pattern. By establishing nation wide consumer information about organic foodstuff the campaign aims at:

- Providing extensive consumer information about organic foodstuff

- Promote the consumption of organic products

- Provide background knowledge about the added value linked to the production methods used in organic farming

- Describe the control of organic foodstuff, which ensures the health of the consumers

- Describe the features of organic foodstuff to the consumers

- Promote the organic label from the EU

The characteristics of each target group is outlined in the table below

\begin{tabular}{|l|l|}
\hline Consumers (households) & $\begin{array}{l}\text { Organic-info-service locations, Brochures, Organic-Action day, } \\
\text { Printed campaign, Public Relation }\end{array}$ \\
\hline Doctors & Information brochure \\
\hline $\begin{array}{l}\text { School children } \\
(10-14 \text { years })\end{array}$ & Teaching material about organic farming \\
\hline $\begin{array}{l}\text { Purchasing agents for large } \\
\text { scale kitchens }\end{array}$ & Handbook to large scale kitchens \\
\hline Specialised staff & Organic fair \\
\hline
\end{tabular}

It is Agrarmarkt Austria (AMA) who is responsible for the project. In 1992 AMA was set up as a market regulation body and agricultural marketing was defined as an additional task. AMA is controlled by the Federal Minister for Agriculture and Forestry, Environment and Water Management. Their campaign started in 2002 and will run for 36 months.

\subsubsection{Denmark - A campaign for the organic EU-logo}

Objective and background of the campaign

The Danish Government is eager to advocate for the development of a proper internal market for organically grown products. Therefore, Denmark launched an information campaign to promote the EU organic logo.

It might seem peculiar that Denmark initiates a campaign for an EU logo as Denmark already have an effective national organic logo - the red $\varnothing-\log 0$ - which is known by $99 \%$ of the Danes. However, the reason is that Denmark wanted to contribute to the further development of the organic sector in the EU. From a Danish point of view, increased trade is 
necessary if the organic sector is to continue to develop. However, crossborder trade with organically grown products is currently limited.

Private and/or national labels and logos have been developed for years. In principle, all products that are produced according to the minimal requirements set out in the EU regulation can be marketed in all EU countries as organic. In many Member States, however, it is not possible to sell products if they do not bear the logo of the national/local inspection body. Further, existence of the large number of national logos makes up a jungle, which is confusing for consumers. On this background the EU organic logo is perceived as a potential common reference that promotes increased trade, and therefore makes up an important supplement to the national logos.

However, the EU logo does not yet seem to be neither fully known nor recognised across Europe. Before the campaign only a few Danish producers applied the EU-logo on their products. This makes it of high importance to promote the logo through an active and committed effort. In this way the Member States themselves are jointly responsible for how long it takes to spread the EU organic logo.

On this background Denmark initiated the campaign to promote the EU organic logo in order to create a more robust and competitive market for organic products.

Campaign theme

The theme for the campaign is "A common European organic logo 'cause the others can't say Ø " ( $\varnothing$ is one of the special Danish letters and used in the organic logo).

The campaign is a further development of a former campaign for the Danish organic logo in 2003, which placed organic food high in the awareness of the consumer. The creative idea is to show that since other Europeans do not know our Danish logo, we must create a common logo.

In a humorous way the campaign shows respectively a Spanish, French, Dutch and Irish EU-citizen trying to read from the Danish rules on organic farming, which is not an easy task due to the language barrier.

Facts about the campaign

The campaign was launched as the end of August 2004 and will run until September 2005.

The campaign targets the entire organic food chain from farmers to processing industry, retail trade and consumers.

Television is the main carrier of the campaign, supported by advertisements in daily newspapers, weekly magazines and trade media, as well as outdoor materials (e.g. posters at train and bus stations) and the Internet. Further, the campaign has its own web-site at www.rodgrod.dk (though the site is only in Danish). 
Further, several retail chains have agreed to support the campaign by using campaign materials (e.g. posters and signs) in the stores. The objective has been also to make the campaign visible at the retail level where the consumers meet the organic products.

Finally, a number of Danish companies within the food sector have committed themselves to put the EU-logo and/or campaign labels on their products. E.g. Denmark's largest dairy company Arla Foods has offered to put information about the EU-logo and the campaign on their milk cartons. The idea has been that it should also be possible actually to see products with the logo on. Otherwise an information campaign for the EU-logo would only have a limited effect. Therefore companies have been requested directly use the logo when the campaign was prepared.

The total budget of the campaign makes up 1,4 million Euro, which is $50 \%$ co-financed by the European Commission (Council Regulation No 2826/ 2000 on information and promotion actions for agricultural products on the internal market).

Behind the campaign

The campaign is being spearheaded by the Danish Ministry of, Agriculture and Fisheries. Further, a reference group has followed and given input to the campaign during its preparation. The reference group consisted of members from the retail trade, the Consumers Council, the Danish Food and Drink Federation, the Danish Agricultural Council, organic Denmark, the Danish Veterinary and Food Administration, the Danish Plant Directorate and the Directorate for Food, Fisheries and Agri Business (Chair). This public-private co-operation has been very valuable in the preparation and implementation of the campaign.

Results of the Danish campaign for the EU organic logo

Nearly one in two Danes (42\%.) are now familiar with the EU organic logo. This is a sharp rise compared to a similar survey last year, which showed only a $7 \%$ awareness of the logo. So, the large-scale Danish information campaign to promote the EU logo has been a success. The experience from Denmark shows that it is possible to achieve a significant effect in a fairly short time.

Observations note an increase in organic products carrying the EU organic logo in Danish shops. This involves both Danish produced organic food and imported organic food products, especially coming from the South of Europe. 


\section{Proposed Initiatives}

This chapter lists potential project activities which will comply with the barriers described in chapter three. Most of the activities are likely to fall within the framework of the Promotion scheme. The chronology of the project activities should not be seen as a hierarchy or prioritisation, but rather as building blocks which a marketing strategy could encompass.

The presentation of each project activity is structured according to:

- Scope of the project (which barriers will it try to overcome)

- Presentation of project elements (target group, timeframe, actors, etc.)

\subsection{Consumer Awareness and Trust}

The development of the organic market depends on the interest of the consumer. Information activities is one way to boost the sales of organic food products.

Activity 1. Information campaign to raise awareness and induce consumers' trust in organic products

A strong profile marketed through story-telling is believed to be a useful tool in building up the consumers' trust in organic products. A direct form of promotion through offensive advertisement could improve consumers' knowledge of the existence and qualities of organic food products. Promotion of organic food systematically and professionally involving different stakeholders in the production chain - from stable to table could prove to be a successful approach, which could target a broad variety of target groups in society.

A large scale information campaign could target:

- Consumers, to evoke recognition of logos, trust in certification/control and awareness of organic production attributes, such as restricted use of pesticides and chemical fertiliser and ban of GMO's,

- Education of primary and secondary school children to improve their knowledge on conventional and organic agriculture and its respective impact on the environment and animal welfare,

- Conventional farmers, motivating them to convert to organic production methods through the establishment of organic demonstration farms,

- Open farms could also inform consumers about organic farming through first hand experiences, 
- Large scale kitchen personnel, educating them to prepare organic food without exceeding their budget,

- Sales personnel in supermarkets, educating them to promote the sale of organic products through awareness rising at the food counter,

\subsection{Deficient Market Transparency}

There is need for greater transparency in relation to rules and standards to avoid bureaucratic and administrative barriers. In the long run greater harmonisation would probably prove to be the most advantageous for organic producers, without compromising the quality and ethics of organic production. Within the geographical framework of this project EU is the most obvious arena for harmonisation. On a larger scale Codex Alimentarius is regarded as the appropriate framework for harmonisation. Until either happens it is important to improve transparency by making information more accessible to stakeholders.

\section{Activity 2. Construction of a common information system on the rules and} procedures

Development of a web based data bank which compared different rules and exposed the differences would be a great asset to the market operators. Attempts to target the production towards a specific market would be facilitated, although the flexibility would still be lacking. The data bank should consist of a guide for market actors on how to export or/and import organic products in the region - a kind of an one-stop-shop. This would ensure that stakeholders would only need to search in one place for the necessary information, which at present is not easy to access.

The need for data encompass:

- Market info concerning retailing channels and alternative sales channels

- Certification procedures and prises for labelling and control schemes

- Differences in rules and standards which newly established labels should comply with to ensure the export potential.

A new research project, co-financed by the Commission within the 6 . Framework Programme ${ }^{33}$, includes the task to set up an internet database, which lists the differences between different national and private standards compared to the EU regulation. The activity within the Nordic/Baltic framework could be based on the outcomes of the project initiated by the EU.

\footnotetext{
${ }^{33}$ FP6: 502327 Research to support revision of the EU regulation on organic agriculture.
} 
It is essential that the collection of data is carried out at a central level to ensure comparable data ${ }^{34}$. In the long run Eurostat is regarded as a suitable platform for improvement in this area and existing data from EUROSTAT should therefor be used as a basis for the activity within the Nordic/Baltic project.

\subsection{Standards and Logos}

The broad variety in labels and differences in standards works as a trade barrier and prohibits the growth of the organic production.

Combining the EU logo with national logos could be one approach increasing of the market potential for organic products. This could promote a more robust and competitive market across borders. The combination of logos would improve the cross-border trade due to a commonly recognised logos and greater harmonisation between rules and standards. Studies show that uniform logo increase consumer recognition of organic products $^{35}$. The promotion of national/private certification labels as well as the EU-logo could be inter-linked the elements described in the information campaign described in section 5.1.

\section{Activity 3. Promotion of the EU-logo and national logos}

Attempts to ensure a high level of recognition of the EU-logo and national logos demands extensive information and promotion campaigns. The EU-logo could pave the way for greater transparency between logos and hereby facilitate an increase in trade with organic produce within the Nordic/Baltic region and the entire European Union. In the long run the organic sector might benefit from a single organic logo - which could be used in parallel with existing national logos. A commonly formulated strategy to promote nationally angled promotion of the EU logo might prove to be a fruitful approach to the effort. As an example of how the EU-logo can be promoted the Danish campaign for the EU-logo has been included in this report (section 4.3.2).

\subsection{Lack of Marketing Channels}

The development of the organic market seem to benefit from a mutual existence of different marketing channels. Supermarkets holds the largest share of the food sales and are needed in order to meet the requirements of the modern urbanised consumer. Alternative channels (local markets,

\footnotetext{
${ }^{34}$ A new research project, co-financed by the European Commission, includes a task to set up an Internet database which lists the differences between different national and private standards compared to the EU regulation.

${ }^{35}$ Commission Working Document, European Action Plan for Organic Food and Farming, June 2004
} 
box schemes, farm-gate-sales etc.) play an important role in relation to consumers looking for direct relations and information about the organic production.

\section{Activity 4. Collaboration between retail chains and representative organic organisations.}

The potential of the supermarket chains could be explored further by initiating co-operation between retail chains and representative organic organisations. Examples of such a project can be seen between the Danish discount chain Netto and the organic organisation, Organic Denmark. It includes that:

- During the next year Netto will actively market organic products in its 334 Danish supermarkets and 57 Swedish supermarkets. This will be done without additional whole sale traders and a raise in the price will be avoided. The chain has agreed to engage in the co-operation to sharpen the company profile in the competition with other chains. Organic Denmark have arranged the contact between the primary producers and Netto. Netto will triple the marketing of organic products and their campaign will include the following themes: fair trade, health and large selection of products. Beyond the regular products, the consumers will be introduced to new low-priced products.

- Netto and Organic Denmark will try to stimulate the development of products through organising a seminar on how new products could find their way to the shelves of the supermarket.

- Netto will invite the consumers to visit organic farmers to gain their own experiences with organic farming.

The co-operation is anticipated to improve the sales by offering organic products at a lower price. Some critiques fear that the trust in the quality of organic products will suffer from stronger inter-linkages with the retailers.

Since projects of this type is dependant on the relationship between the retailers and the organic organisations, the establishment of a Nordic/Baltic network between the latter could prove useful in order to exchange project experiences. The promotion of regional networking could induce such exchange.

\section{Activity 5. Alternative distribution channels}

The mutual existence of both large scale and small scale distribution channels entail initiatives in several directions.

- The establishment of alternative distributions channels could be based on a network oriented approach. The primary producers could thereby 
avoid rejection of their products by the supermarkets due to problems with the packaging and small volumes.

- An interactive internet-based network could be established as a joint contact point for primary producers. The homepage could target both retailers and consumers. Targeting retailers could entail pooling of raw products to obtain larger volumes and thereby overcoming obstacles related to small scale volumes, like high transportation costs per unit etc. This project would also serve as a form of project for lowering prices. Targeting consumers could entail exposing freshly grown products through a homepage. To compensate for the lack of direct contact with the farmers, as is the case for farm-gate-sales, each farmer could present themselves with photos and story-lines about their lives on the farm. This would especially target urban communities who are less likely to visit the country side and shop at farm-gate-sales. 


\section{From Idea to Action}

The Steering Committee discussed the prospects of a future project during the final meeting 23-24 January in Jelgava, Latvia. It was the purpose of the meeting to clarify which project elements from chapter 5 each member could express an interest in and their national possibilities of cofinancing.

\subsection{Meeting Conclusions}

The Steering Committee agreed that there is a need for a flexible campaign concept in order to target local and national needs. This means that the listed project elements in the previous chapter should be considered as eligible elements that the participating countries can choose from as part of an overarching campaign. Each activity constitutes a building stone in a campaign for development of the organic market according to the overall scope of this project.

The Danish Secretariat committed itself to elaborate an overall concept which could provide a common denominator and an overarching framework for a campaign in which all the nations can participate. The idea of a concept is the important role of tying a common campaign together thematically, in terms of messages and press strategy. On the other hand the concept should allow flexibility and local adaptation. Each participating country would also have to provide national co-financing.

The Steering Committee agreed to keep a close look at initiatives and ideas coming from the European Commission. Both in order to avoid overlaps but also to establish a win-win situation where everybody could benefit from the lessons learned within the Steering Committee.

\section{List of Literature}

Chapter 1

European Commission, "European Action Plan for Organic Food and Farming", Commission Working Document, June 2004

Willer and Yussefi (Eds.), The World of Organic Agriculture - Statistics and Emerging Trends 2004.
Chapter 2

Denmark

Fibiger Norfelt, "Organic Farming in Denmark" 2003, http://www.organiceurope.net/country reports/Denmark /default.asp

NYT fra Danmarks Statistik, Emnegruppe: Landbrug, Udenrigshandel med økologi- 
ske varer, Nr. 511 29. november 2004, Statistics Denmark 2003

Plantedirektoratet, "Statistik over økologiske jordbrugsbedrifter 2003”, juni 2004

Estonia

Merit Mikk, "Organic Agriculture in Estonia 2001" http://www.organiceurope.net/country_reports lestonia/default.asp

Summary of Estonian seminar on the Nordic-Baltic market project for organic food

Finland

Heinonen, "Organic Farming in Finland" 2002 www.organiceurope.net/country reports/finland /default.asp

"En markedsrapport om Norge, Sverige og Finland med fokus på dagligvarehandelen", Økologi i Norden, 2004.

("A market report on Norway, Sweden and Finland, focusing on retail business", Ecology in the Nordic Region, 2004)

Latvia

Report from the Ministry of Agriculture; "An Overview for the year 2003" http://www.zm.gov.lv/data/overview_20 03.pdf

Report from the Ministry of Agriculture; "Agriculture and Rural Area of Latvia", 2004

http://www.zm.gov.lv/data/gz 29.09.200 4(2).doc

Kreismane, Presentation on organic farming in Latvia, Helsinki 2004

Lithuania

“Agriculture in Lithuania 2004", Ministry of Agriculture of the Republic of Lithuania http://terra.zum.lt/agri04/073.htm "Organic Farming in Lithuania". Background paper provided by the Ministry of Agriculture of the Republic of Lithuania.

Norway

"En markedsrapport om Norge, Sverige og Finland med fokus på dagligvarehandelen”, Økologi i Norden, 2004.

("A market report on Norway, Sweden and Finland, focusing on retail business", Ecology in the Nordic Region, 2004)

Johnsen and Mohr, "Organic Agriculture in Norway" for Organic-Europe. http://www.organic-europe.net/country reports /norway/default.asp

Landbruksdepartementet, "Økologisk mat", Fishnet Nordic AS, 2002

"Statistikk 2002 - Økologisk produksjon”, Debio

"Statistikk 2003 - Økologisk produksjon", Debio

http://www.debio.no/section.cfm?id=1\& subid $=175$

The New EU Member States gets help to Implement Organic Control”, External Forum - The external newsletter from the Ministry of Agriculture and Food. Week letter No. 43, 20 October 2004

Sweden

Dirke, "Development of the Nordic-Baltic market for Organic food", Swedish Workshop, November 2004

Holmberg, "Konsumentundersökning om ekologiske produkter/krav", report for KRAV og LRF, 1999

"Jordbruksstatistisk Årsbog 2004"

http://www.jordbruksverket.se/startsida/amnesomraden/statistikfakta/ja/ja2004/innehallpdf2 004.4.7502f61001ea08a0c7fff104561.ht $\underline{\mathrm{ml}}$

Källander, "Organic Agriculture in Sweden" http://www.organic-

europe.net/country_reports/Sweden/default.a sp

KRAV, "Årsrapport" 2003

Willer and Yussefi (Eds.),"The World of Organic Agriculture - statistics and emerging trends", 2004 www.soel.de/inhalte/publikationen/s/s_ 7 4.pdf

Chapter 3

Council Regulation (EEC) No. 2092/91 of 24 June 1991 on organic production of agricultural products and indications referring thereto on agricultural products and foodstuffs.

EISFOM 2004, "Development of a European Information System for Organic Markets - improving the Scope and Quality of Statistical Data". http://www.fibl.org/shop/pdf/st-1339eisfom-2004.pdf

European Commission, "European Action Plan for Organic Food and Farming", Commission Working Document, 10 June 2004 
European Commission, "Commission Staff Working Paper - Analysis of the possibility of a European Action plan for organic food and farming", 12 December 2002

Eurostat report on Organic farming in EU15.

http://www.eisfom.org/links/eurostat.pdf Hamm and Gronefeld, "The European Market for Organic Food: Revised and Updated Analysis", OMIaRD, volume 5, 2004. Published by: The University of Wales, UK and School of Management and Business, UK.

Michelsen et al. : "The European Market for Organic Products: Growth and development", Series: Organic Farming in Europe: Economics and Policy Volume 7

"The World of Organic Agriculture statistics and emerging trends. http://www.oel.de/inhalte/publikationen/ s/s 74.pdf

Willer and Yussefi (Eds.), "The World of Organic Agriculture - Statistics and Emerging Trends", 2004.

http://www.soel.de/inhalte/publikationen /s/s 74.pdf
Chapter 4

Council Regulation (EC) No 2826/2000 of 19 December on information and promotion actions for agricultural products on the internal market.

Commission Regulation (EC) No. 94/2002 of 18 January 2002 laying down detailed rules for applying Council Regulation (EC) No 2826/2000 on information and promotion actions for agricultural products on the internal market

Commission Regulation (EC) No $1803 / 2004$ of 15 October 2004 on the change of regulation (EC) No 94/2002 on the detailed rules for applying Council Regulation (EC) No 2826/2000 on information and promotion actions for agricultural products on the internal market.

Council Regulation (EC) No. 2060/2004 of 22 November 2004 on the change of regulation (EC) No. 2702/1999 information and promotion actions for agricultural products on the internal market 


\section{Sammenfatning}

Denne rapport indeholder konklusionerne fra projektet "Udvikling af det nordiske og baltiske marked for økologiske fødevarer", hvor repræsentanter fra myndigheder og NGO'er fra Danmark, Estland, Finland, Letland, Litauen, Norge og Sverige har deltaget.

Målet med projektet har været at udarbejde et forslag til et fælles samarbejdsprojekt for at understøtte udviklingen af det Nordisk-baltiske marked for økologiske produkter.

Rapporten identificerer og beskriver en række barrierer for en markedsdreven udvikling af den økologiske sektor, herunder begrænset forbrugeroplysning, mangel på markedsdata, forskellige standarder og mærkningsordninger, mangel på markedsføringskanaler, mangel på forarbejdning og innovation samt et generelt højt prisniveau.

På baggrund af de identificerede barrierer foreslår rapporten en række potentielle tværnationale projektaktiviteter mellem landene, herunder informationskampagne til at øge forbrugernes kendskab til de økologiske produkter, udvikling af et informationssystem om de enkelte landes regler og procedurer, udbredelse af EU-logo'et og nationale logo'er, samarbejde mellem detailkæder og repræsentative økologiske organisationer og udvikling af alternative distributionskanaler.

Med henblik på gennemførelse af en eller flere af disse tværnationale projektaktiviteter, er relevante støttemuligheder blevet undersøgt. EU's interne promotionsordning (Kommissionens lovgivning (EC) 94/2002 fra 18. januar 2002) vurderes at være den mest relevante støttemulighed, og er derfor beskrevet indgående i rapporten.

Det skal understreges at projektets deltagere ikke er bundet af konklusionerne af projektet. Derfor står det åbent for enhver at udarbejde en ansøgning om støtte og at arbejde videre på forslagene. Direktoratet for FødevareErhverv vil udarbejde et overordnet konceptforslag, som kan skabe en fællesnævner og en fælles struktur for en kampagne, hvor alle lande kan deltage. 


\title{
Annex 1: Relevant Links
}

\author{
International Organisations, Businesses and Research Institutions
}

IFOAM: The international coalition of organisations within organic farming

organic-europe: European site with overview of reports of organic farming in 25 European countries.

organic-research: Information on research, education and activities within organic farming. Also contains and extensive database of scientific articles

Link-organic: Links to businesses and trade organisations

Organic Eprints : Organic Eprints is an international open access archive for papers related to research in organic agriculture. The archive contains full-text papers in electronic form together with bibliographic information, abstracts and other metadata

EcoWiki: A tool for doing cooperative work on the internet. The site is targeted towards organic agriculture and food systems, and related areas. You can edit webpages and add new pages by using suitable WikiWords. You can also show images, upload files, and do a range of more sophisticated stuff if you wish.

\section{Research Centres}

Centrum för uthålligt lantbruk (CUL), Sverige

Norsk senter for økologisk landbruk (NORSØK), Norge

Mikkeli Institute for Rural Research and Training, Finland

Organic Agriculture Centre of Canada, Canada

Partala Forskningsstation för ekologiskt lantbruk, Finland

Louis Bolk Institute, Holland

Research Institute of Organic Agriculture (FiBL), Switzerland

Elm Farm Research Centre, UK

Organic Centre Wales, UK

Stiftung Ökologie \& Landbau (SÖL), Tyskland

Danish Research Centre for Organic Farming, Denmark

\section{Current European Organic Research Partnerships}

CORE Organic, Coordination of European Transnational Research in Organic Food and Farming. Core Organic initially comprises of 11 partners but is open to include all countries with a national research programme for organic food and farming.

QualityLowInputFood, QualityLowInputFood is an integrated project funded by the European Commission. It is designed to generate the 
knowledge required to implement the priority themes of the European Union's Sixth Framework Programme of Research and Technological Development. 


\section{Annex 2: Organic Market Share in Norway, Sweden and Finland}

Table: Market share and development for certain organic product categories Norway $^{36}$

\begin{tabular}{|c|c|c|c|c|c|c|c|}
\hline & $\begin{array}{l}\text { Meat and } \\
\text { Charcuterie }\end{array}$ & $\begin{array}{l}\text { Fruits and } \\
\text { vegetables }\end{array}$ & Cereals & $\begin{array}{l}\text { Bakery } \\
\text { products }\end{array}$ & $\begin{array}{l}\text { Dairy } \\
\text { products }\end{array}$ & $\begin{array}{l}\text { Non- } \\
\text { dairy } \\
\text { drinks }\end{array}$ & Eggs \\
\hline Market volume & & & & & & 2,3 & \\
\hline $\begin{array}{l}2003 \text { (Euro) } \\
\text { Yearly growth in } \\
\text { market (1999- }\end{array}$ & 2,2 mill. & 15 mill. & 1,5 mill. & 3,05 mill. & 12 mill. & mill. & 1,7 mill. \\
\hline 2002) & $15 \%$ & $18 \%$ & $10 \%$ & $10 \%$ & $5 \%$ & $22 \%$ & $8 \%$ \\
\hline $\begin{array}{l}\text { Estimated yearly } \\
\text { growth (2004- }\end{array}$ & & & & & & & \\
\hline 2006) & $10 \%$ & $4 \%$ & $6 \%$ & $8 \%$ & $2 \%$ & $13 \%$ & $1 \%$ \\
\hline $\begin{array}{l}\text { Ecological market } \\
\text { share }\end{array}$ & $<0,1 \%$ & $0,1 \%$ & $0,5 \%$ & $0,5 \%$ & $0,6 \%$ & - & $0,6 \%$ \\
\hline
\end{tabular}

Table : Market share and development for certain organic product categories - Sweden ${ }^{36}$

\begin{tabular}{|c|c|c|c|c|c|c|}
\hline & $\begin{array}{l}\text { Meat and } \\
\text { Charcuterie }\end{array}$ & $\begin{array}{l}\text { Fruits and } \\
\text { vegetables }\end{array}$ & Cereals & $\begin{array}{l}\text { Bakery } \\
\text { products }\end{array}$ & $\begin{array}{l}\text { Dairy } \\
\text { products }\end{array}$ & $\begin{array}{l}\text { Non-dairy } \\
\text { drinks }\end{array}$ \\
\hline \multicolumn{7}{|l|}{ Market volume } \\
\hline $\begin{array}{l}2003 \text { (Euro) } \\
\text { Yearly growth in } \\
\text { market (1999- }\end{array}$ & 60 mill. & 100 mill. & 10 mill. & 6 mill. & 80 mill. & 7 mill. \\
\hline 2002) & $22 \%$ & $18 \%$ & $8 \%$ & $8 \%$ & $15 \%$ & $30 \%$ \\
\hline $\begin{array}{l}\text { Estimated yearly } \\
\text { growth (2004- }\end{array}$ & & & & & & \\
\hline 2006) & $2 \%$ & $2 \%$ & $4 \%$ & $4 \%$ & $5 \%$ & $6 \%$ \\
\hline $\begin{array}{l}\text { Organic market } \\
\text { share }\end{array}$ & $2 \%$ & $3 \%$ & $1 \%$ & $2 \%$ & $2 \%$ & - \\
\hline
\end{tabular}

Table : Market Share and Development for certain Organic Product Categories - Finland ${ }^{37}$

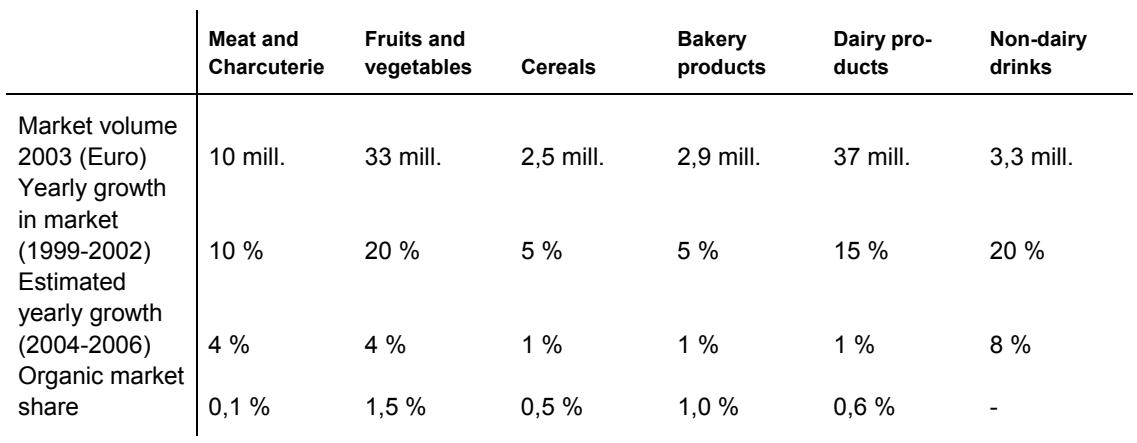

\footnotetext{
${ }^{36}$ Organic Monitor, 2003

${ }^{37}$ Source: Organic monitor, Eggs are left out of the table, since Finish retail sale only will sell eggs produced in Finland because of fear of salmonella in foreign produced products.
} 
Table 10, 11 and 12 display the organic market share is distributed among different food groups in Finland, Sweden and Norway in 2003. Sweden's organic market is by far the largest, worth 263 mill. Euro, followed by Finland, worth 88,7 mill. Euro and Norway, worth 37,5 mill. Euro.

The growth experienced between 1999 and 2002 is expected to fall dramatically for all product categories in the three countries, while the highest expectations are linked to the Norwegian market who have the lowest organic market (between $<0,1 \%-0,6 \%$ ). According to this research the Swedish market has matured to the level of a saturated market with more moderate growth rates compared to previous years. 